\title{
The adoption process in Management Innovation: a Knowledge Management case study
}

Journal of Information Science

$1-15$

(c) The Author(s) 2015

Reprints and permissions: sagepub.co.uk/journalsPermissions.nav DOI: I0.1 I77/016555|5I0000000 jis.sagepub.com

\section{Louise Rasmussen}

Centre for Social Informatics, Edinburgh Napier University, UK

\author{
Hazel Hall \\ Centre for Social Informatics, Edinburgh Napier University, UK
}

\begin{abstract}
This paper draws on findings from a longitudinal study of the adoption of a management innovation within an organisational setting. It is based on the findings of a case study that explores and discusses in depth a Knowledge Management programme that was introduced within a large distributed public sector agency in Europe. The aim of this research was to provide insight into the adoption process associated with management innovation. A qualitative case study strategy generates an account of the process of adoption through three phases (initiation; implementation; and outcomes), the episodes within each phase, and decision-making across the entire process. The findings contribute to the development of an extended and refined model of the process of adoption of management innovation through the consideration of the labelling, sequence and transition of phases and episodes, and decisionmaking. In this extended and refined model there are three phases with nine episodes, two of which are recursive; the phases occur in a linear sequence but may overlap, whilst the episodes occur in a non-linear sequence; and decision-making occurs within episodes, between phases, and between episodes. The study makes three primary contributions to knowledge. First, it considers the process of adoption (as opposed to the more commonly examined process of generation) of management innovation. Second, it identifies decision-making related to the changes required for adoption of a management innovation. Finally, it develops a model of the process of adoption of management innovation that includes decision-making. In addition, the output of the study can be used as a tool for project management by identifying the questions to be addressed, and the decisions to be made, at particular points of the management innovation process, taking into account local contexts.
\end{abstract}

\section{Keywords}

Knowledge Management; management innovation; process of adoption; public sector

\section{Introduction}

This paper reports the findings of a longitudinal case study research into a Knowledge Management (KM) programme that was introduced to maximise the value of information and knowledge assets within an organisational setting. The research addressed the question: 'What does a detailed study of a KM implementation reveal about the process of adoption of a management innovation?' The case in question is a large, distributed, European public sector agency that uses task forces for the management and delivery of its services. The scope of the work discussed here refers to a time period of 13 years.

Management innovations are practices that are identified in the external environment then generated, or adopted (and often modified) within organisations to further organisational goals with resulting impacts on managerial work. The KM implementation under scrutiny here can be conceived as a 'management innovation' on the basis that the programme in question exhibited the four main characteristics of a management innovation as defined in [1] and [2]. Namely:

(1) It exhibited novelty/newness.

(2) It was implemented in practice. 
(3) It was intended to further organisational goals.

(4) It had an impact on how managerial work was conducted within the case study organisation.

A literature review prefaces the main findings of the study. With reference to earlier theoretical models of the process of adoption of management innovations, and consideration of decision-making as a key activity over the course of the adoption, the literature review presents KM as a management innovation. Attention is then focused on the case study organisation with an account of its adoption of KM across three phases: initiation, implementation, and outcomes. This analysis reveals that each of the three phases comprises several episodes, and decision-making occurs across all three phases. The findings from the case study are considered with reference to the earlier literature review. This allows for the extension of a proposed model of the process of adoption of a management innovation through analysis of: (1) the labelling of phases and episodes found to be evident in practice; (3) the sequence of, and transition between, phases and episodes; and (4) decision-making at different points across the whole process.

This case study provides new insight into: (1) the detail of the process of adoption of management innovation (which has been neglected in the research to date in favour of greater attention to the process generation); (2) decision-making related to organisational change, and/or to KM; and (3) how practices related to the process of adoption of management innovation (including decision-making) can be modelled.

\section{Literature review}

\section{I. Knowledge Management as a management innovation}

Research into innovation at an organisational level covers new developments in terms of: (1) product and service features or intended uses; (2) processes of production or delivery of products and services; (3) methods of marketing products or services; and/or (4) improved business practices, organisational structures, or external relations [3, pp 1617]. These developments are typically labelled 'product', 'service', 'process', 'marketing', and 'organisational' innovation [3].

In recent years research has drawn attention to a subfield of organisational innovation labelled 'management innovation' (for example, [4] [5] [6] [7]). This comprises new management processes, practices, structures and techniques designed to engender competitive advantage [4, p. $822 \&$ p. 825]. Management innovations relate to a number of business functions, such as: managing business processes (for example, business process re-engineering); reporting on operations (for example, balanced scorecard); managing human resources (for example, 360-degree feedback); structuring organisations (for example, matrix organisation); managing customer and partner relations (for example, customer relationship management); and determining strategic direction (for example, scenario planning) [5, pp.vi-vii].

Much has been published on the role of KM in innovation processes, both in the information science literature (for example, [8]) and beyond (for example, [3] [9] [10] [11]). Less attention, however, has been paid to KM as an innovation in its own right [12]. Of particular interest to the study reported here is that although KM has not previously been articulated as a management innovation, it may be conceived as such. This is on the basis that KM shares the four main characteristics of management innovation (see [1] and [2]), as illustrated in Table 1.

Table I. Characteristics of KM as a management innovation

\begin{tabular}{ll}
\hline Management innovation characteristics & Knowledge Management characteristics \\
\hline Exhibits novelty/newness & KM has been perceived as new by academics since the 1960s [13] and by \\
& practitioners since the 1970s [14]. \\
Implemented in practice & KM shows evidence of implementation across a range of organisational \\
& settings (as noted, for example, by [15] [16] [I7]). \\
Intended to further organisational goals & KM intends to enhance organisational competitiveness and innovativeness \\
& at a strategic level [3, p. 88] [16, p. I2] and improve effectiveness and \\
efficiency at an operational level (for example, [I7] [18]). & KM focuses managers' attention on leveraging the knowledge of human \\
Impacts on how managerial work is conducted & resources [16] [17]. This knowledge perspective has the potential to \\
& significantly alter how managerial work is performed [19].
\end{tabular}




\subsection{Models of the innovation process}

There are the two main processes associated with innovation (in general) at an organisational level. These are labelled 'generation' and 'adoption' [20]. Previous research into management innovation has been primarily concerned with generation (for example, [4] and [5]), understood as the creative process that results either in an innovation that, up to that point, has been unknown, or one that is distinctive from pre-existing innovations [21].

Despite the detailed analyses of the components of the first main process (generation), there remains a lack of indepth knowledge of adoption (the second). Little is known about the phases and episodes involved in how organisations become aware of management innovations, and then acquire, adapt and use them [20, p. 447]. This is not to say, however, that discussion of the adoption of management innovations is missing in the extant literature. Indeed, many papers on this broad theme can be readily identified. Prior work [4] has classified the existing studies as generally taking one of four perspectives: the 'institutional' perspective, which considers the adoption of management innovation with reference to socioeconomic conditions; the 'fashion' perspective, which examines the interplay between providers and users of management innovations; the 'cultural' perspective, which considers the reaction to the introduction of management innovations; and the 'rational' perspective, which reveals how management innovations deliver organisational improvements. What is lacking here, however, are studies that examine the entire process of adoption in detail, taking into account its components and associated decision making. Detailed consideration of the adoption of management innovation from a 'processual' perspective is thus absent in the literature.

While there are numerous general innovation models, there are only two that have been labelled 'management innovation'. These are the models described by Birkinshaw \& Mol in 2006 [5] and Birkinshaw, Hamel and Mol in 2008 [4]. Both are concerned with the process of generation (rather than adoption) of management innovation in organisational settings. Of the extensive number of general innovation models, three others (in addition to the work of Birkinshaw, Hamel \& Mol cited above) are of direct relevance to the research reported here. All three were initially proposed by Rogers in his 2003 text Diffusion of innovations [22]. First, the model of the innovation-development process is important because it relates to generation processes above [22, p. 138]. Second, the model of the innovationdecision process is closely tied with the process of adoption of innovation in organisations [22, p. 170]. This is because this model focuses on the process of individual or group decision-making in adopting innovations. Finally, the model of the innovation-adoption process is relevant because it is concerned with the adoption of innovations in organisational settings [22, p. 421].

The five models cited above were considered together to create a consolidated model of the process of adoption that could be tested in practice in a case study organisation. Figure 1 shows that despite a lack of agreement from existing model to model, three main phases of the adoption of a management innovation - initiation, implementation and outcomes - can be identified, and that a number of episodes map to each phase, as articulated in each of the five models. It can also be seen that although the labelling of episodes differs from model to model, there is commonality in the activities that they describe. Attention is also drawn to the theme of decision-making in the models, which is elaborated in further detail below. 


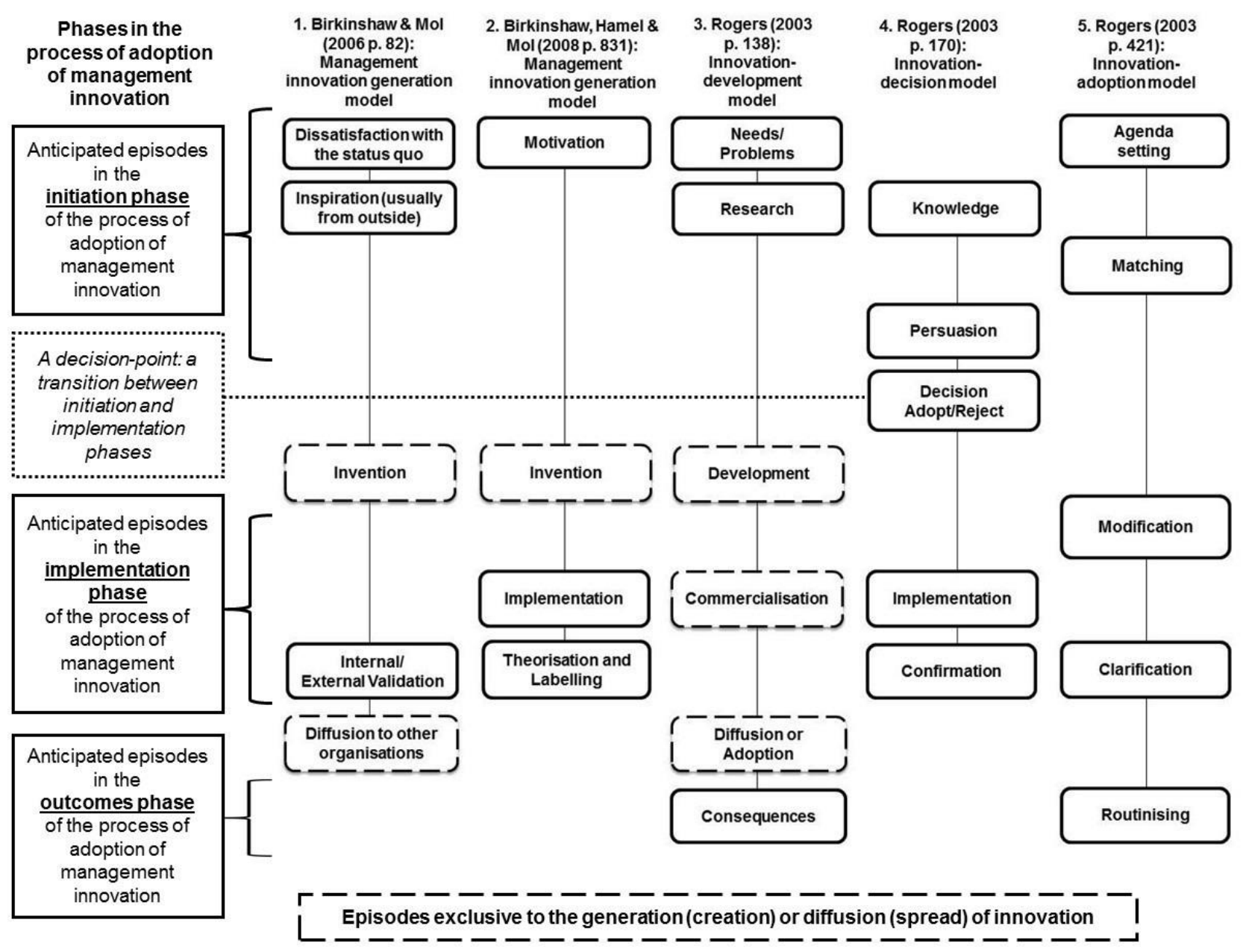

Figure I. A comparison of innovation models (sources: [4] [5] [2I])

\subsection{Decision-making in the adoption of management innovations, and as related to $K M$}

Decision-making is widely discussed in the innovation literature (for example, [22]), as well as in the management literature (for example, [23]). Decisions that frequently involve making choices between alternatives are labelled 'decisions between alternatives' [24, p. 198]. In the innovation literature Rogers [22] highlights one such decision between alternatives: a decision to either adopt, or to reject, an innovation. Researchers who study the adoption process have focused on adoption or rejection decisions to explain the transition (or not) between phases and episodes, for example [22].

Rogers' innovation-adoption model and innovation-decision model are depicted as two separate processes in the extant literature [22]. Here, however, they are considered together, as shown in Figure 2. It can be seen in this figure that decisions to adopt or reject an innovation can take place at a number of points across the adoption process. The figure also shows how a decision can be made to discontinue an adoption, even after routinisation has occurred.

A decision to adopt an innovation marks a transition from one phase to another [22] [25, p. 99]. A decision may also be made to reject an innovation after routinisation has occurred [22]. This marks a transition between two possible episodes (discontinuation or routinisation) in the outcomes phase of the adoption process. Although these two outcomes have not been depicted in extant models of innovation, they feature in the narrative of the literature [22 p. $138 \&$ p. 190]. 


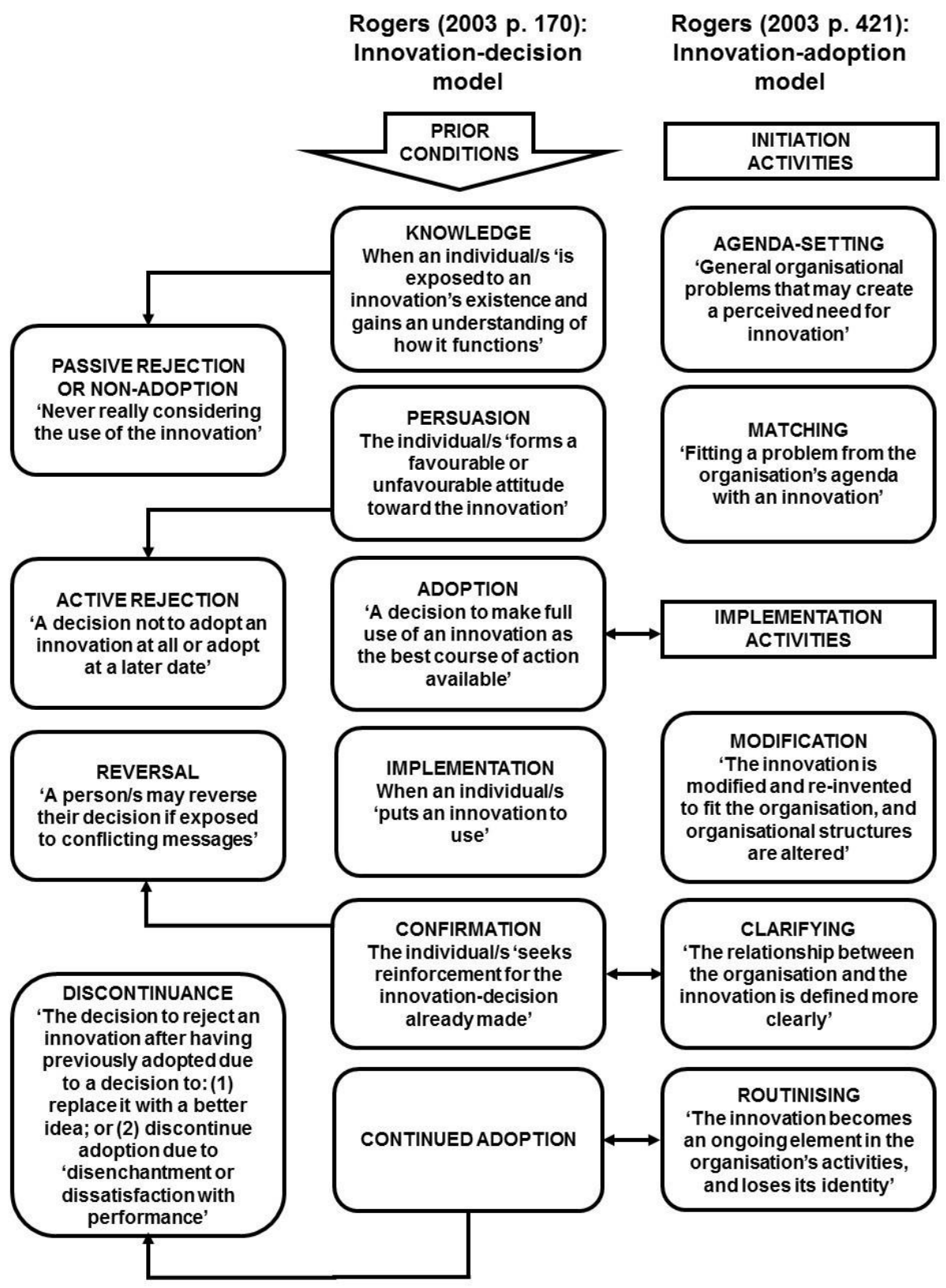

Figure 2. The interrelationship between the innovation decision and innovation adoption model (source: [22])

In the specific case of KM, there are many decisions between alternatives to consider. Types of decisions between alternatives are presented in Table 2. 
Table 2. Decisions between alternatives for the adoption of $\mathrm{KM}$ as a management innovation

\begin{tabular}{|c|c|}
\hline Decision relates to: & Examples of alternatives: \\
\hline \multirow[t]{2}{*}{ Focus of agenda for change } & Furthering organisational goals (e.g. facilitate organisational change) \\
\hline & Enhancing firm performance (e.g. improve organisational impacts) \\
\hline \multirow[t]{2}{*}{ Depth of change } & Conceptual (deep) change that affects organisational culture \\
\hline & Practical (shallow) change that affects organisational practices \\
\hline \multirow[t]{2}{*}{ Extent of change } & Broad across all organisational functions \\
\hline & Narrow within one or more (but not all) organisational functions \\
\hline \multirow[t]{2}{*}{ Direction of change } & Top-down from experts to local users \\
\hline & Bottom-up from local users to peers \\
\hline \multirow[t]{2}{*}{ KM strategy } & Personalisation (people-focused) strategy \\
\hline & Codification (technology-focused) strategy \\
\hline \multirow[t]{2}{*}{ KM approach } & Push innovation approach identifying needs/problems of potential KM users \\
\hline & Pull problem approach identifying local needs/problems to address through KM \\
\hline \multirow[t]{2}{*}{ KM participation } & Mandatory, where participants do not have a choice to adopt or reject KM \\
\hline & Voluntary, where participants have a choice to adopt or reject KM \\
\hline \multirow[t]{2}{*}{ KM modifiability } & KM can extend vertically across organisational hierarchy \\
\hline & KM can extend horizontally across organisational boundaries \\
\hline \multirow[t]{2}{*}{ KM operationalisation } & Initial trial experimentation with a few potential users \\
\hline & 'Big bang' style full roll-out to all potential users \\
\hline \multirow[t]{2}{*}{ KM staffing } & A specific single specialist task force appointed for the implementation \\
\hline & Use of individuals or groups to implement KM \\
\hline \multirow[t]{2}{*}{ KM outcomes } & Include $\mathrm{KM}$ in organisational routines \\
\hline & Discontinuance the use of $\mathrm{KM}$ \\
\hline \multirow[t]{2}{*}{ KM discontinuance } & Discontinue KM due to dissatisfaction \\
\hline & Discontinue KM by replacing it with something better \\
\hline
\end{tabular}

\subsection{A consolidated model of the process of adoption of management innovation}

Drawing on the literature cited above, it is possible to present a theoretical model of the process of adoption of management innovation, as presented in Figure 3. This model derives from an analysis of the two extant models of management innovation [4] [5], and the three other general, well-cited, innovation models (innovation-development; innovation-decision; and innovation-adoption in organisations) [22]. This consolidated model posits that management innovation is a process that comprises three phases (initiation; implementation; and outcomes), and each phase is made up of non-linear episodes. Decision-making takes place across the whole process.

\begin{tabular}{ll}
\hline Phase & Anticipated episodes \\
\hline I. Initiation & Agenda-setting \\
& Knowledge/research \\
& Matching \\
& Persuasion \\
Between phase decision point: & $\begin{array}{l}\text { adopt or reject management innovation } \\
\text { 2. Implementation }\end{array}$ \\
& Modification \\
& Operationalisation \\
3. Outcomes & Clarification/confirmation \\
& Discontinuation \\
& Between episode decision point: continue adoption of management innovation, or reject it \\
\end{tabular}

Figure 3. A consolidated model of the process of adoption of a management innovation

The consolidated model uses terms that are mainly drawn from Rogers' (2003) innovation-decision and innovationadoption models [22]. There are, however, four labelling exceptions at episode level: 
(1) The label 'operationalisation' is used instead of 'implementation' so as to avoid an episode having the same name as a phase.

(2) The labels 'clarification' and 'routinisation' are used instead of 'clarifying' and 'routinising' so that all the episodes in phase 2 and 3 are labelled as nouns

(3) The label 'discontinuation' is used instead of 'consequences' to draw a clear contrast with 'routinisation'.

It is the model presented in Figure 3 that was tested in a 'live' environment as part of the study reported in this paper, with the intention of generating further insight into the process of adoption of management innovation. The means by which this was achieved is outlined below.

\section{Research design: site selection, material collection and data analysis}

The findings reported here derive from an extensive study that focused on an exploration of the process of adoption of $\mathrm{KM}$ as a management innovation in an organisational setting. The site for data collection was PuSA. PuSA is a large national public sector agency responsible for economic development in a European country. The organisation directs its operations from a headquarters office in a major city through twelve distributed agencies. Across the full period covered in this research PuSA employed a minimum of 1500 and a maximum of 2500 staff.

The research approach adopted for this study was inductive. Qualitative multi-methods were deployed to gather and analyse data for a longitudinal timeframe of 13 years (1995-2008). The main focus of the analysis was the extent to which the phases and episodes articulated together in Figure 3 are applicable in the adoption of KM, conceptualised here as a management innovation. Its ultimate goal was to provide additional insight on the adoption process associated with management innovation. This is an underexplored theme in both the innovation and KM literature, as has been highlighted above.

Materials for analysis were collected from electronic sources generated over the full 13-year period, and from participant observations made over five of these years during which time the first author was an employee of PuSA. She led and executed the research processes as described below (including data gathering, coding and analysis) in consultation with the second author. Two main types of materials were gathered for analysis. The first comprised historical archive material generated within PuSA between 1995 and 2003. The second set can be classed as 'situated material' on the basis that it was gathered in situ between 2003 and 2008. These materials comprised 8732 documents and online files, 4567 e-mail threads and extensive field notes. Once assembled, the materials were sorted into electronic folders by theme and categories in a case study database.

From a close analysis of the materials it was possible to construct a chronological timeline of the KM implementation between 1995 and 2008. The chronology referred to the milestones and events in the implementation, as well as to the textual material gathered to evidence its development. As preparation for drawing conclusions from the chronological data, codes were then assigned manually to the data. This follows practice in processual research [26] and longitudinal case study research [27].

Manual coding of the data facilitated the identification of phases and episodes of this particular management innovation. From these codes it was also possible to expose decision-making points across the adoption process. The analysis conducted on the data that referred to milestones, events, and texts on the chronological timeline of the KM implementation revealed that phases and episodes in the first iteration of the consolidated model (Figure 3) were evident in practice at PuSA. This is discussed further below with reference to specific findings drawn from the analysis.

\section{Findings}

Table 4 summarises the activities related to the process of adoption of the management innovation as evidenced in the data collected in the case study. 
Table 4. PuSA activities observed from analysis of the empirical data collected in the research

\begin{tabular}{|c|c|c|c|}
\hline Phase: episode & Activities observed & $\begin{array}{l}\text { Evidence of activities from empirical } \\
\text { data sources }\end{array}$ & $\begin{array}{l}\text { File formats and } \\
\text { date of source } \\
\text { material }\end{array}$ \\
\hline \multirow[t]{2}{*}{ Initiation: agenda-setting } & $\begin{array}{l}\text { Defining a general } \\
\text { organisational need/problem } \\
\text { to address }\end{array}$ & $\begin{array}{l}\text { Identification of the need to facilitate } \\
\text { knowledge sharing across the organisation }\end{array}$ & $\begin{array}{l}\text { PowerPoint file, } \\
1999\end{array}$ \\
\hline & $\begin{array}{l}\text { Setting the agenda for } \\
\text { organisational change }\end{array}$ & $\begin{array}{l}\text { Approval from Board members of the } \\
\text { implementation of business transformation } \\
\text { projects }\end{array}$ & Word file, 2000 \\
\hline \multirow[t]{2}{*}{$\begin{array}{l}\text { Initiation: } \\
\text { knowledge/research }\end{array}$} & $\begin{array}{l}\text { Gaining awareness of } \\
\text { organisational needs/problems } \\
\text { Gaining awareness of } \\
\text { management innovation } \\
\text { serendipitously or through } \\
\text { planned research }\end{array}$ & $\begin{array}{l}\text { Headquarters staff undertake reviews of } \\
\text { organisational structure and operations } \\
\text { Planned research undertaken to assess KM } \\
\text { leading practice in other organisations }\end{array}$ & $\begin{array}{l}\text { Word file, } 1999 \\
\text { Intranet page, } 2000 \\
\text { Word file, } 2000\end{array}$ \\
\hline & $\begin{array}{l}\text { Gaining knowledge of how the } \\
\text { management innovation } \\
\text { works, and what it is meant to } \\
\text { do }\end{array}$ & $\begin{array}{l}\text { Consultants present an overview of KM } \\
\text { solutions, including reasons for their } \\
\text { adoption }\end{array}$ & $\begin{array}{l}\text { PowerPoint file, } \\
2000\end{array}$ \\
\hline \multirow[t]{3}{*}{ Initiation: matching } & $\begin{array}{l}\text { Selecting a management } \\
\text { innovation to match the } \\
\text { agenda for organisational } \\
\text { change }\end{array}$ & $\begin{array}{l}\text { Development of an intranet, communities } \\
\text { of and 'knowledge packs' to facilitate } \\
\text { knowledge sharing across the organisation }\end{array}$ & Intranet pages, 200 I \\
\hline & $\begin{array}{l}\text { Selecting and planning } \\
\text { organisational structures for } \\
\text { delivery }\end{array}$ & $\begin{array}{l}\text { Headquarters staff Introduce an } \\
\text { organisational structure that includes a KM } \\
\text { task force }\end{array}$ & $\begin{array}{l}\text { PowerPoint file, } \\
2002\end{array}$ \\
\hline & $\begin{array}{l}\text { Anticipating enablers and } \\
\text { barriers to management } \\
\text { innovation implementation }\end{array}$ & $\begin{array}{l}\text { Identification of staff behaviours that are } \\
\text { not conducive to sharing knowledge across } \\
\text { the organisation }\end{array}$ & $\begin{array}{l}\text { PowerPoint file, } \\
1999\end{array}$ \\
\hline \multirow[t]{4}{*}{ Initiation: persuasion } & $\begin{array}{l}\text { Persuading staff to adopt the } \\
\text { management innovation }\end{array}$ & $\begin{array}{l}\text { Roadshow held in subsidiaries to explain } \\
\text { the necessity for transformation projects, } \\
\text { including KM }\end{array}$ & Word file, 2000 \\
\hline & & $\begin{array}{l}\text { Development of } K M \text { intranet site to } \\
\text { provide an overview of } K M \text {, an overview of } \\
\text { the KM project, and information on } K M \\
\text { tools }\end{array}$ & Intranet pages, 200 I \\
\hline & & $\begin{array}{l}\text { Publication of all staff newsletters that } \\
\text { outline KM task force staff appointments } \\
\text { and } K M \text { tools chosen for adoption }\end{array}$ & \\
\hline & $\begin{array}{l}\text { Seeking validation for } \\
\text { management innovation } \\
\text { adoption from internal and } \\
\text { external sources. }\end{array}$ & $\begin{array}{l}\text { External consultants appointed during } \\
\text { business transformation to help staff } \\
\text { develop KM solutions }\end{array}$ & Word file, 2000 \\
\hline $\begin{array}{l}\text { Implementation: } \\
\text { modification }\end{array}$ & $\begin{array}{l}\text { Modifying organisational } \\
\text { structures to accommodate } \\
\text { management innovation or } \\
\text { vice versa. }\end{array}$ & $\begin{array}{l}\text { KM tools are added to the toolkit, and } \\
\text { consultancy process developed to support } \\
\text { KM } \\
\text { delivery at subsidiary level }\end{array}$ & $\begin{array}{l}\text { Various emails, } \\
\text { Word/PDF files, } \\
\text { intranet pages 2002- } \\
2007\end{array}$ \\
\hline $\begin{array}{l}\text { Implementation: } \\
\text { operationalisation }\end{array}$ & $\begin{array}{l}\text { Rolling out management } \\
\text { innovation for the first time - } \\
\text { as trial experiment or in full }\end{array}$ & $\begin{array}{l}\text { Roll-out of community-inspired intranet, } \\
\text { and implementation of KM tools are } \\
\text { implemented on a trial or ad-hoc basis }\end{array}$ & $\begin{array}{l}\text { Various emails and } \\
\text { Word/PDF files, } \\
\text { 2002-2007 }\end{array}$ \\
\hline \multirow[t]{2}{*}{$\begin{array}{l}\text { Implementation: } \\
\text { clarification/confirmation }\end{array}$} & $\begin{array}{l}\text { Clarifying and making sense of } \\
\text { management innovation in } \\
\text { situ. }\end{array}$ & $\begin{array}{l}\text { Attempts to clarify the roles of subsidiary } \\
\text { Knowledge Analysts (i.e. distributed } \\
\text { members of the KM task force), and the } \\
\text { what KM comprises }\end{array}$ & $\begin{array}{l}\text { Various email, } \\
\text { Word/PDF files, } \\
\text { researcher field } \\
\text { notes, } 2002-2007\end{array}$ \\
\hline & Seeking confirmation for & Survey initiated by KM directorate to & Email, 2004 \\
\hline
\end{tabular}


continued adoption

Outcomes: routinisation

Outcomes: discontinuation
Continuing adoption so that management innovation becomes routine and standard practice

Ceasing adoption of management innovation due to disenchantment or dissatisfaction with performance determine whether staff believe: (I) the KM task force structure is appropriate; and (2) the KM task force has the necessary skills to implement KM

Assessment of health of existing

Word file, 2005 communities of practice by external consultant

Agreement of KM priorities amongst subsidiary staff made at behest of KM

Word file, 2005

Director

KM Director re-labels the KM teams

'Information Management' and

'Organisational Learning', and disbands the

KM community of practice
Emails, 2006

Detailed analysis of the findings revealed that the consolidated model of the process of adoption of a management innovation (Figure 3) can be further extended and refined with reference to:

(1) The labelling of phases and episodes

(2) The sequence of phases and episodes

(3) Decision-making across the process

These adaptations are discussed in detail below.

\section{I. The labelling of phases and episodes}

Table 5 shows that the broad articulation of the adoption of management innovation through three phases, as proposed in the development of the consolidated model in Figure 3, can be observed in practice. A contribution of this study is thus confirmation of these three distinct phases.

Table 5. Phases and episodes of management innovation identified in the empirical study

\begin{tabular}{lll}
\hline Phase & Anticipated episodes & $\begin{array}{l}\text { Episodes identified from the empirical } \\
\text { study }\end{array}$ \\
\hline I. Initiation & $\begin{array}{l}\text { Agenda-setting } \\
\text { Knowledge/research } \\
\text { Matching }\end{array}$ & $\begin{array}{l}\text { Agenda-setting } \\
\text { Knowledge/research } \\
\text { Selection/matching }\end{array}$ \\
& $\begin{array}{l}\text { Persuasion } \\
\text { Persuasion/validation }\end{array}$ \\
Between phase decision point: adopt or reject management innovation & Modification \\
2. Implementation & $\begin{array}{l}\text { Modification } \\
\text { Operationalisation } \\
\text { Clarification/confirmation }\end{array}$ & $\begin{array}{l}\text { Operationalisation } \\
\text { Clarification/confirmation }\end{array}$ \\
Discontinuation & Discontinuation \\
& Between episode decision point: continue adoption \\
of management innovation, or reject it & \\
& Routinisation & Routinisation \\
\hline
\end{tabular}

Findings from the empirical study prompted the relabelling of two episodes: 'matching' becomes 'selection/matching', and 'persuasion' becomes 'persuasion/validation'. For the former, this reflects that (a) KM tools were selected to match the agenda for sharing knowledge across the organisation, and (b) a task force was selected to facilitate the implementation of these KM tools in the initiation phase of the adoption process at PuSA. A further reason for the addition of term 'selection' is preference for its use over matching in the KM literature (for example, [11]). The 
term 'validation' is combined with 'persuasion' to take into account the marketing activities, such as staff roadshows, introduced at PuSA to validate the introduction of KM.

\subsection{The sequence of phases and episodes}

A further key finding from this study is that the phases and episodes have to be considered separately: the distinction between each of the three phases (initiation, implementation, and outcomes) was clearly identifiable in PuSA. However, it is not the case that each phase runs in sequence, where one starts at the point that the previous one ends. Rather, the phases may overlap. As far as episodes are concerned, their sequencing was confirmed at PuSA to be non-linear within each phase. This finding aligns with arguments presented in the prior literature (for example, [4] [11] [28] [29]). In addition, episodes may occur at the same time. This was evident in PuSA where the implementation and modification episodes ran in parallel. For example, a number of modifications to the KM programme were introduced alongside attempts to operationalise the three initial KM tools selected (communities of practice, and intranet, and knowledge packs).

A further finding from this study is that the agenda-setting and knowledge/research episodes are recursive. The data analysed for this study revealed how PuSA identified a general organisational need/problem, i.e. to change a knowledge-oriented organisation. This motivated an external search for new (albeit pre-existing) approaches that could address the need for knowledge sharing across the organisation. It was through this extended search that additional opportunities for management innovation were found. This, in turn, resulted in the identification of more specific organisational needs/problems to address. Although discussed in earlier published work [22 pp 171-172], this recursive cycle of agenda-setting and knowledge/research is not depicted in extant models of innovation.

\subsection{Decision-making across the process}

The output from empirical work confirms that decision-making in the adoption of a management innovation occurs at three points:

(1) Within episodes: decisions relate to organisational change, and/or to the management innovation in question (which, in this case, is KM)

(2) Between phases: decisions relate to further adoption or rejection of the management innovation, and in the case of further adoption lead into the transition from one phase to another

(3) Between episodes: a decision to reject (or discontinue) after routinisation has occurred

The empirical work conducted for this study revealed that groups of decisions take place within specific episodes of the three phases of a management innovation. Table 6 provides an overview of the groups of inter-related decisions between alternatives that were identified at PuSA. 
Table 6. Groups of inter-related decisions in the adoption of $\mathrm{KM}$ as a management innovation

\begin{tabular}{|c|c|c|}
\hline \multicolumn{2}{|c|}{ Decision groups $(\mathrm{I}-5)$} & \multirow{2}{*}{$\begin{array}{l}\text { Decisions between alternatives (and/or decisions) } \\
\text { Furthering organisational goals (e.g. facilitate organisational change) }\end{array}$} \\
\hline 1 & Agenda for change & \\
\hline & & Enhancing firm performance (e.g. improve organisational impacts) \\
\hline & Depth of change & Conceptual (deep) change that affects organisational culture \\
\hline & & Practical (shallow) change that affects organisational practices \\
\hline \multirow[t]{8}{*}{2} & Extent of change & Broad across all organisational functions \\
\hline & & Narrow within one or more (but not all) organisational functions \\
\hline & Direction of change & Top-down from experts to local users \\
\hline & & Bottom-up from local users to peers \\
\hline & KM approach & Push innovation, identifying needs/problems of potential KM users \\
\hline & & Pull problem, identifying needs/problems to address through KM \\
\hline & KM modifiability & Vertical extension of KM across organisational boundaries \\
\hline & & Horizontal extension of $\mathrm{KM}$ across organisational hierarchies \\
\hline \multirow[t]{4}{*}{3} & KM strategy & Personalisation (people-focused) strategy \\
\hline & & Codification (technology-focused) strategy \\
\hline & $\mathrm{KM}$ resources & Single specialist task force appointed for the implementation \\
\hline & & Various individuals or groups implement KM \\
\hline \multirow[t]{4}{*}{4} & KM participation & Mandatory, where participants do not have a choice to adopt or reject KM \\
\hline & & Voluntary, where participants have a choice to adopt or reject $\mathrm{KM}$ \\
\hline & KM operationalisation & Initial trial experimentation with a few potential users \\
\hline & & 'Big bang' style full roll-out to all potential users \\
\hline \multirow[t]{4}{*}{5} & KM outcomes & Include KM in organisational routines \\
\hline & & Discontinue the use of $\mathrm{KM}$ \\
\hline & KM discontinuation & Discontinue KM due to dissatisfaction \\
\hline & & Discontinue KM by replacing it with something better \\
\hline
\end{tabular}

The analysis revealed that the adoption of KM as a management innovation is aided when there is compatibility of decision making. This applies both within, and across, decision groups. For example, if the agenda for change (the first element of decision group 1) is to further organisational goals through the facilitation of organisational change, then the required depth of change (the second element in decision group 1) is conceptual (deep) so that it has the desired impact on organisational culture. For the sake of compatibility with these decisions in group 1, the extent of change (the first element of decision group 2) needs to be broad across all organisational functions; the direction of change (the second element of decision group 2) should be top-down; the KM approach (the third element of decision group 2) should be push-innovation; and the modifiability (the fourth element of decision group 2) such that KM will extend horizontally across organisational boundaries.

A lack of compatibility across decision-making threatens the adoption of a management innovation. In this case decision-making in the agenda-setting and selection/matching episodes of the initiation phase that was incompatible with decision-making in the implementation phase had negative consequences at PuSA. For example, the decision to introduce a distributed KM task force that reported to different managers in different locations meant the focus of KM efforts was on delivering KM at a subsidiary, rather than, pan-organisational level. This was at odds with an established agenda for fostering knowledge sharing across the organisation. It also necessitated efforts to facilitate subsidiary delivery of KM in the modification episode of the implementation phase of adoption. These had corresponding negative impacts on the operationalisation and clarification/confirmation episodes. Difficulties were experienced in implementing $\mathrm{KM}$ in an environment where local practice differed in the subsidiaries. For example, there was great variety of how staffing was resourced in the subsidiaries where those in KM roles were recruited to different timescales, contracts, grades and salary scales and had a range of job titles, competencies, roles and measures of performance. In addition the purpose of the implementation was not well-understood due to the resulting mix of approaches adopted across different parts of the organisation. Such issues are further compounded in a management innovation when there is ad-hoc operationalisation in the absence of clear decision-making in the initiation phase. In this case no explicit decisions were made regarding KM strategy, the approach (pull or push), and degree of staff participation, nor to incorporate the KM tools into PuSA's policies, processes or procedures. This put the adoption of the implementation as a whole at PuSA at risk. 


\section{Discussion: an extended and refined model of the process of adoption of management innovation}

The aim of this study was to provide additional insight on the adoption process associated with management innovation. First, a consolidated model that includes decision-making was generated from the innovation literature to test in an empirical setting (Figure 3). This model is supported by groups of decisions between alternatives (see Table 2). From the findings of the empirical study above, together with the evaluation of literature, an extended and refined model of the process of adoption of management innovation can generated, as depicted in Figure 4 below.

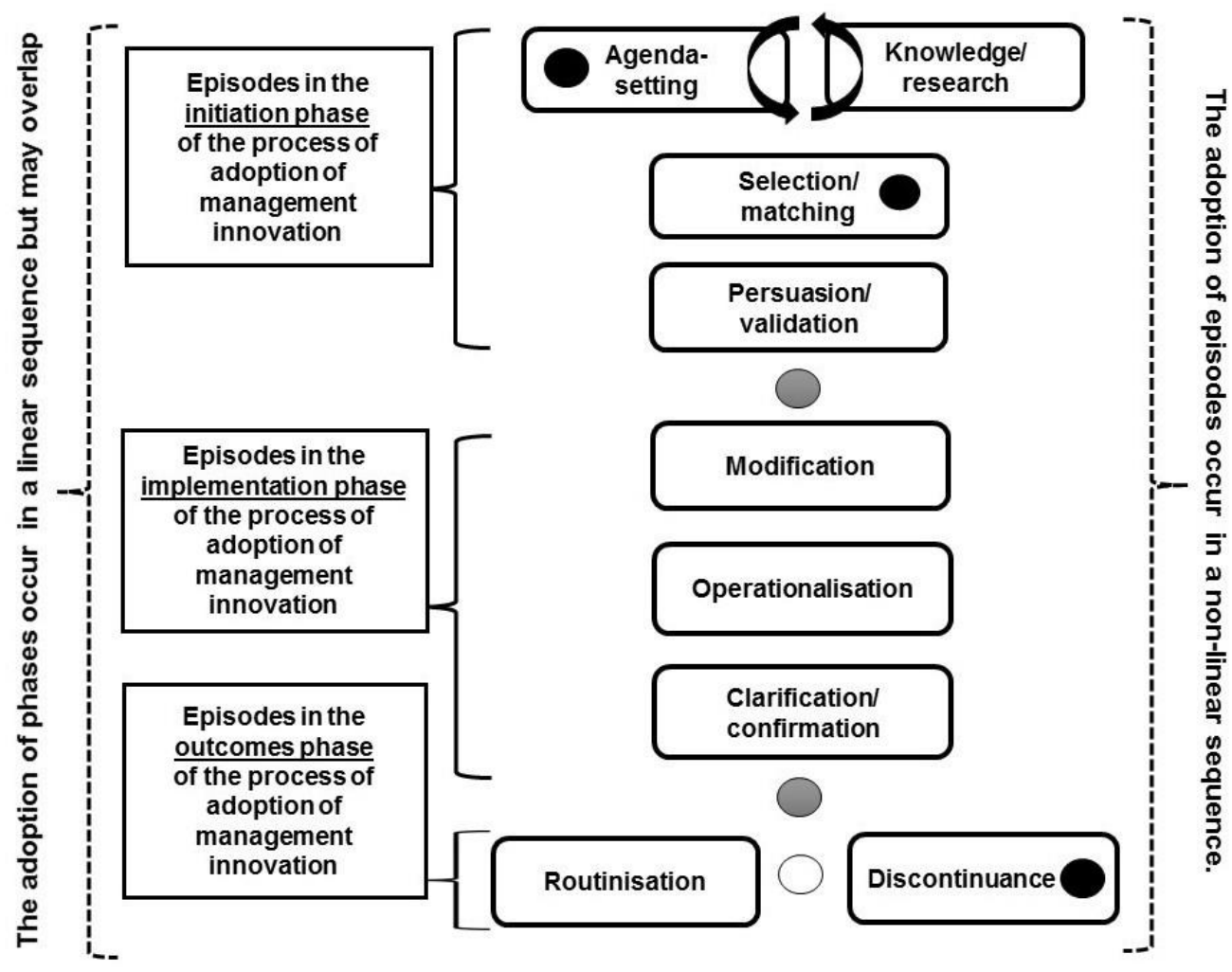

Three distinct decision-points:

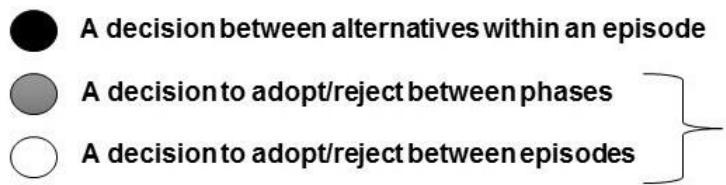
Decisions to adopt or reject can take place across the process. There are, however, two distinct adoption/ rejection decision points.

Figure 4. An extended and refined model of the process of adoption of a management innovation

Of note is how this extended and refined model differs from Rogers' (2003) general innovation-adoption model [22] (see Figure 2). The main differences are:

- The initiation phase in the extended and refined model includes a modified episode (knowledge/research) and a new episode (persuasion/validation)

- In the implementation phase the extended and refined model presents a further a modified episode (clarification/confirmation)

- Between the implementation and outcomes phase in the extended and refined model there is a decision-point that marks the between-phase transition 
- A further phase labelled 'outcomes' with an additional discontinuance episode is included in the extended and refined model

- The extended and refined model features decision-making points within episodes

- There is a decision-making point between the discontinuance and routinisation episode in the extended and refined model

The novelty of the inclusion of 'outcomes' as an additional phase, and 'discontinuance' as one of the episodes in this phase is worth consideration here. Models of innovation rarely consider failure as a possible outcome. While this proinnovation bias has been observed in both the innovation literature [22, p.106] and KM literature [30], it is not common practice to draw attention to this possibility, especially in a graphical representation of innovation. Figure 4 addresses this criticism of prior work in the domain.

The extended and refined model has resulted from a piece of research that comprised the in-depth testing of a consolidated model of the process of adoption of management innovation (Figure 3) in a single live setting. It is recommended that future research assess and test the applicability of this new model in other types of organisations that have adopted management innovations. Of particular value would be studies over longer time periods so that an adoption can be explored in full to the point of routinisation/discontinuance. Such work would acknowledge the finding of this study, also noted in [31], which suggests that to determine the continued routinisation and/or subsequent discontinuance of $\mathrm{KM}$ and associated organisational impacts, researchers need to gather material for data analysis over a period of a decade or more.

In any future assessment of the applicability of the extended and refined model attention should focus on: the omission of episodes; the sequencing of episodes; and transition between episodes. Such work will address factors evident in the extant literature that remain under-explored. These include such as the extent to which all episodes are evident in the innovation process; the ease of identification of episode sequences in the adoption of highly complex innovations; and transitions between episodes in organisational settings where decision-making is executed in an informal manner. The sequencing of decisions, and decisions between alternatives, is also worth further scrutiny. The empirical work discussed here shows that key decisions take place in two episodes: agenda-setting and selection/matching. This may not be representative of the sequence of decision-making in other organisational settings. It would also worth investigating whether the decisions between alternatives are reflective of all 'generic' decisions taken in the process of adoption of management innovation in general, as well as with respect to KM as a management innovation.

A further recommendation is that data collected in future similar studies use methods additional to those deployed in the study discussed here. Local constraints imposed by PuSA meant that it was not possible, for example, to interview or survey staff at PuSA. Had such data been analysed in conjunction with the documentary evidence and observations in situ, as is the case in mainstream case study research (as opposed to the approach described here which could be considered akin to techniques more readily deployed in the arts and humanities, such historical methods or in discourse analysis), it would have been possible to assess whether the staff at large were aware of, or recognised the phases and episodes in the adoption process of KM within their place of work, and organisational decision-making related to the implementation.

\section{Conclusion}

This work set out to generate new insight about the process of adoption of a management innovation, This has been achieved through an in-depth investigation of a KM programme in a European public sector organisation. The study makes three primary contributions: (1) it widens understanding of the process of adoption of management innovation (a process that, to date, has been neglected in favour of the process of generation); (2) it identifies decision-making related to the changes required for adoption of a management innovation; and (3) it has developed a model of the process of adoption of management innovation that includes decision-making. These contributions are theoretically significant because, to date, no attempt has been made to model decision-making for the process of adoption of management innovation (in general), or KM. Nor has any attempt been made to draw on the prior literature, and significantly Rogers' (2003) innovation-adoption and innovation-decision models [22], to form a model for the adoption of management innovations in organisational settings. In addition, unlike the earlier studies of the adoption of management innovation, the research discussed here focused on processes. As such it adds a fifth perspective - 'processual' - to the classifications of management innovation research, as previously identified in the literature [4] (as noted in section 2.2 above). 
The extended and refined model of the process of adoption of management innovation is also of practical use to those who seek to adopt KM within organisations, particularly because it can be used as a project management tool for the identification of phases and episodes to consider during the process of adoption, and decisions to be made at various points across the process. This practical usefulness of the work distinguishes it from other studies that consider the evolution of KM through stages (for example [32] [33]), ages (for example [34]), phases (for example [35]), and generations (for example [36] [37]). These prior studies are significant because they provide necessary explanations of how the domain has matured over time, and is achieved, for instance, with reference to the focus of KM strategies (such as codification to personalisation), or by drawing attention to the theoretical underpinning for delivering KM in practice (for example with reference to philosophical interpretations of fundamental terms and research perspectives). However, such work is often of low practical value to those engaged in navigating the process of adoption of knowledge management in practice in organisational settings. In contrast, by exposing the process of adoption of KM as a management innovation, and drawing attention to decision making related to the acquiring, adapting and deploying components of $\mathrm{KM}$, this study provides insight that is both useful in practice and adds to theoretical development within the domain.

\section{Notes}

1. Rogers (2003 p. 421) uses the label 'innovation process in organisations'

\section{Acknowledgements}

The authors acknowledge the case study organisation, and (people) for the study reported here, and Dr Karen Atkinson in the preparation of the manuscript.

\section{Funding}

The first author received funding towards this study from PuSA in 2004/05 and 2005/06, and was awarded a UKeiG Student Bursary in 2008/09 and The John Campbell Trust Scholarship in 2010/11.

\section{References}

[1] Birkinshaw J, Hamel G and Mol, MJ. Management innovation. Advanced Institute of Management Research. Working Paper Series, 21 July 2005.

[2] Mol MJ and Birkinshaw J. Giant steps in management: innovations that change the way we work. New York: Prentice-Hall, 2008.

[3] [4OECD and Eurostat. Oslo Manual: Guidelines for collecting and interpreting technological innovation data. Report for the OECD, Europe, 2005 3rd ed.

[4] Birkinshaw J, Hamel G and Mol MJ. (2008). Management innovation. Academy of Management Review, 2008; 33(4) 825845.

[5] Birkinshaw J and Mol MJ. How management innovation happens. MIT Sloan Management Review, 2006; 47(4) 81-88.

[6] Mol MJ and Birkinshaw J. Management Innovation in the UK. Report for Department for Innovation, Universities and Skills 09-07, 2009a

[7] Mol MJ and Birkinshaw J. (2009b). The sources of management innovation: When firms introduce new management practices. Journal of Business Research, 2009b; 62(12) 1269-1280.

[8] Auernhammer J and Hall H. Organizational culture in knowledge creation, creativity and innovation: towards the Freiraum model. Journal of Information Science, 2014; 40(2), 154-166.

[9] Darroch J. Knowledge management, innovation and firm performance. Journal of Knowledge Management, 2005; 9(3), 101115.

[10] Du Plessis M. The role of knowledge management in innovation. Journal of Knowledge Management, 2007; 11(4), $20-29$.

[11] Newell S, Robertson M, Scarbrough H et al. Managing knowledge work and innovation. 2nd ed. Basingstoke: Palgrave McMillan, 2009.

[12] Grant K. Knowledge Management, an enduring but confusing fashion. Electronic Journal of Knowledge Management, 2011; 9(2) 117-131.

[13] Lambe P. The unacknowledged parentage of knowledge management. Journal of Knowledge Management, 2011; 15(2) 175197.

[14] Wiig KM. Comprehensive knowledge management, Texas: Knowledge Research Institute, Inc. http://www.krii.com/downloads/comprehensive_km.pdf (1999, accessed 28 September 2015)

[15] Lam, W and Chua, A. The mismanagement of knowledge management. Aslib Proceedings, 2005; 57(5) $424-433$. 
[16] Dalkir K. Knowledge management in theory and practice. 2nd ed. Cambridge, MA: Massachusetts Institute of Technology, 2011.

[17] Jashapara A. Knowledge management: an integrated approach.2nd ed. Harlow, Essex: Pearson Education, 2011.

[18] Schultze U and Leidner DE. Studying knowledge management in information systems research: discourses and theoretical assumptions. MIS Quarterly, 2002; 26(3) 213-242.

[19] Hamel G. The why, what, and how of management innovation. Harvard Business Review, February 2006.

[20] Damanpour F and Aravind, D. Managerial innovation: conceptions, processes, and antecedents. Management and Organization Review, 2012; 8(2) 423-454.

[21] Damanpour F and Wischnevsky JD. Research on organizational innovation: distinguishing innovation-generating from innovation-adopting organizations. Journal of Engineering and Technology Management, 2006; 23 269-291.

[22] Rogers EM. Diffusion of Innovations. 5th ed. London: Simon \& Schuster, 2003.

[23] De Oliviera, M.G., Rozenfeld, H., Phaal, R. \& Probert, D. Decision making at the front end of innovation: the hidden influence of knowledge and decision criteria. R\&D Management, 2015; 45(2), 161-180.

[24] Rollinson D, Broadfield A and Edwards DJ. Organisational behaviour and analysis. An integrated approach. Harlow: Addison Wesley, 1998.

[25] Gopalakrishnan S and Damanpour F. Patterns of generation and adoption of innovation in organizations: contingency models of innovation attributes. Journal of Engineering and Technology Management, 1994; 11 95-116.

[26] Poole MS, Van de Ven AH, Dooley K et al. Organizational change and innovation processes: theory and methods for research. New York: Oxford University Press, 2000.

[27] Yin RK. Case study research: design and methods. 3rd ed. Thousand Oaks, CA: Sage Publications Ltd., 2003.

[28] Van de Ven AH. Central problems in the management of innovation. Management Science, 1986; 32(5) $590-607$.

[29] Cheng YT and Van de Ven AH. Learning the innovation journey: order out of chaos? Organization Science, 1996; 7(6) 593614.

[30] Hall H and Goody M. KM, culture and compromise: interventions to promote knowledge sharing supported by technology in corporate environments. Journal of Information Science, 2007; 33(2) 181-188.

[31] Milton, N. (2014). Global KM Survey: How long does it really take for KM to bed in? http://www.nickmilton.com/2014/08/how-long-does-km-really-take-to-bed-in.html (2004 accessed 28 September 2015)

[32] Koenig, M.E.D. The third stage of KM emerges. KM World, 2002; 11(3), 20-21.

[33] Hsieh, P.J., Lin, B., \& Lin, C. The construction and application of knowledge navigator model (KNMTM): An evaluation of knowledge management maturity. Expert Systems with Applications, 2009; 36(2), 4087-4100.

[34] Snowden, D. Complex acts of knowing: paradox and descriptive self-awareness. Journal of Knowledge Management, 2002; 6(2), 100-111.

[35] Wei, J., Lee, J. \& Hsu, C. The evolution of knowledge management: current and future application in China. What is Knowledge? In Proceedings of the 7th Pacific Asia Conference on Information Systems, 2003, Adelaide, Australia, pp. 12681284.

[36] Rezgui, Y., Hopfe, C.J., \& Vorakulpipat, C. Generations of knowledge management in the architecture, engineering and construction industry: an evolutionary perspective. Advanced Engineering Informatics, 2010; 4(2), 219-228.

[37] Vorakulpipat, C., \& Rezgui, Y.An evolutionary and interpretive perspective to knowledge management. Journal of Knowledge Management, 2008; 12(3), 17-34. 